\title{
DESAIN PEMBANGKIT LISTRIK TENAGA SURYA PADA DAERAH PESISIR KUALA TUNGKAL TANJAB BARAT
}

\author{
Ir. H. Myson, MT
}

\begin{abstract}
Abstrak
Energi surya (matahari) merupakan salah satu sumber energi terbarukan yang paling penting dan sangat berlimpah di Indonesia. Dengan potensinya yang sangat besar tersebut, energi surya diyakini menjadi sumber energi utama di masa depan. Eenergi surya di Indonesia sangatlah besar. Indonesia memiliki sekitar $4.8 \mathrm{KWh} / \mathrm{m} 2$ atau setara dengan $112.000 \mathrm{GWp}$ energi surya. Sayangnya energi surya ini belum mendapatkan porsi yang semestinya di negara ini. Dari total potensi energi surya tersebut, Indonesia baru memanfaatkan sekitar 10 MWp. Hambatan yang masih sering terjadi pada penggunaan PLTS ini adalah pada tidak dapatnya diprediksi keacaan cuaca dalam waktu yang singkat, sehingga produksi energi listrik sulit dapat memenuhi target yang diharapkan, dan hal ini membuat ketidak nyamanan pengguna. Perlunya penelitian terhadap efisiensi modul solar panel, karena saat ini efisiensi yang dihasilkan modul solar panel masih sangat rendah, sehingga untuk mendapatkan $1 \mathrm{KWh}$ energi listrik masih tergolong sangat mahal.
\end{abstract}

\begin{abstract}
Solar energy (sunlight) is one of the renewable energy sources the most important and very abundant in Indonesia. With such huge potential, solar energy is believed to be the main energy source in the future. Solar Eenergi in Indonesia is very large. Indonesia has around $4.8 \mathrm{KWh} / \mathrm{m} 2$ or equivalent to $112,000 \mathrm{GWp}$ of solar energy. Unfortunately, solar energy has not received the proper portion of the country. Of the total solar energy potential, Indonesia has only utilized approximately $10 \mathrm{MWp}$. Barriers are still common in the use of solar power is at the inability to predict the weather keacaan in a short time, so the production of electrical energy is difficult to meet the expected targets, and this makes it an inconvenience for the user. The need for research on the efficiency of solar panel modules, because the current efficiency of the resulting solar panel module is still very low, so to get $1 \mathrm{kWh}$ of electrical energy is still relatively very expensive.
\end{abstract}

Keyword : Energi surya, surya, solar panel, Kuala Tungkal Panel Surya 


\section{PENDAHULUAN}

Energi surya adalah energi yang berupa panas dan cahaya yang dipancarkan matahari. Energi surya (matahari) merupakan salah satu sumber energi terbarukan yang paling penting. Indonesia mempunyai potensi energi surya yang sangat berlimpah. Namun melimpahnya sumber energi surya di Indonesia belum dimanfaatkan secara optimal.

Salah satu cara untuk memanen radiasi panas dan cahaya yang dipancarkan matahari menjadi listrik adalah dengan memanfaatkan teknologi termal dan teknologi sel surya atau sel photovoltaic. Teknologi termal biasanya digunakan untuk mengeringkan hasil pertanian dan perikanan, memasak (kompor surya), dan memanaskan air. Sedangkan sel surya merupakan alat untuk mengconversi cahaya matahari menjadi energi listrik dengan menggunakan efek fotoelektrik. Dengan teknologi sel surya (photovoltaic) energi surya diubah menjadi energi listrik yang bisa digunakan untuk berbagai hal.

Dengan potensinya yang sangat besar tersebut, energi surya diyakini menjadi sumber energi utama di masa depan. Apalagi dengan beberapa keunggulan energi surya seperti energi surya merupakan sumber yang hampir tak terbatas dan ramah lingkungan. Yang hingga kini masih menjadi kendala adalah teknologi sel surya dan media penyimpanan yang masih sangat mahal dan memiliki kemampuan yang terbatas.

Untuk Indonesia, energi surya menjadi salah satu alternatif energi yang terbaik. Dengan potensinya yang besar tersebut akan mampu melepaskan Indonesia dari ketergantungan terhadap sumber energi konvensional. Energi surya sangat cocok diterapkan pada daerah-daerah terpencil maupun pulau-pulau kecil di Indonesia. Pemanfaatan energi surya menjadi salah satu sumber energi alternatif ini bisa dilakukan dengan membangun Pembangkit Listrik Tenaga Surya (PLTS) maupun Solar Home System (SHS), yaitu pemanfaatan skala rumahan.

Sebagai wilayah yang berada di kawasan khatulistiwa, potensi energi surya di Indonesia sangatlah besar. Indonesia memiliki sekitar $4.8 \mathrm{KWh} / \mathrm{m} 2$ atau 
setara dengan 112.000 GWp energi surya. Sayangnya energi surya ini belum mendapatkan porsi yang semestinya di negara ini. Dari total potensi energi surya tersebut, Indonesia baru memanfaatkan sekitar $10 \mathrm{MWp}$.

Sementara jumlah kebutuhan energi, khususnya energi listrik untuk wilayah pesisisr dan kepulauan sangatlah belum terpenuhi. Untuk memecahkan permasalahan ini maka perlu dikembangkan pembangkit listrik energi baru terbarukan khususnya energi surya untuk wilayah pesisir pantai dan kepulauan, baik mandiri maupun yang terpusat. Salah satu wilayah di Indonesia yang sampai saat ini mengalami defisit energi listrik dan posisinya berada di pesisir adalah kota Kuala Tungkal Kab Tanjung Jabung Barat Prov Jambi.

Tujuan penelitian kali ini adalah untuk mengetahui seberapa potensialkah pembangkit listrik tenaga surya dapat dimanfaatkan pada kotaKuala Tungkal yang berada di pesisir pantai di kabupaten Tanjung Jabung Barat. Selain itu penelitian ini juga bertujuan untuk mengetahui seberapa besar radiasi matahari yang diterima pada titik yang ditentukan di daerah tersebut dan juga untuk menghitung rata-rata radiasi sinar matahari yang dapat dikonversikan menjadi energi listrik pada daerah tersebut.

Dengan dilakukannya penelitian ini diharapkan masyarakat pada daerah pesisir dan kepulauan khususnya di kota Kuala Tungkal dapat membuat sendiri pembangkit listrik untuk memenuhi kebutuhan listrik mereka. Dan apabila telah memiliki pembangkit listrik tenaga surya ini, diharapkan meraka dapat melaksanakan perawatan terhadapat sistim dan peralatan pembangkit tersebut.

Matahari adalah sumber energi yang memancarkan energi sangat besarnya ke permukaan bumi. Permeter persegi permukaan bumi menerima hingga 1000 watt energi matahari. Sekitar 30\% dari energi tersebut dipantulkan kembali keluar angkasa, dan sisanya diserap oleh awan, lautan, dan daratan. Jumlah energi yang diserap oleh atmosfer, lautan, dan daratan bumi sekitar 3.850.000 eksajoule (EJ) 
per tahun. Untuk melukiskan besarnya potensi energi surya yang diterima bumi dalam waktu satu jam saja setara dengan jumlah energi yang digunakan dunia selama satu tahun lebih.

Matahari merupakan bintang yang jaraknya paling dekat dengan bumi. Matahari merupakan bintang ukuran sedang, dengan ukuran sekitar 110 kali bumi. Matahari terbentuk sekitar 4,6 milyar tahun yang lalu. Berasal dari debu-debu angkasa, yang saling tarik-menarik antar partikelnya hingga membentuk massa yang besar. Pengaruhnya terhadap kehidupan di bumi sangat luas. Tiap detik, setiap meter persegi atmosfer luar bumi menerima rata-rata 1.324 watt, cukup untuk menghidupkan 10 bola lampu. Jumlah yang jatuh per detik sama dengan energi hasil pembakaran 6,4 juta ton batu bara per detik. Energinya mentenagai sirkulasi udara, cuaca, dan air, serta segala kehidupan di Bumi.

Sel surya atau sel photovoltaic merupakan suatu alat yang dapat mengubah energi radiasi matahari secara langsung menjadi energi listrik. Pada dasarnya sel tersebut berjenis diode yang tersusun atas $\mathrm{P}-\mathrm{N}$ junction. Sel surya photovoltaic yang dibuat dari bahan semi konduktor yang diproses sedemikian rupa, yang dapat menghasilkan listrik arus searah (DC). Dalam penggunaannya, sel-sel surya itu dihubungkan satu sama lain, sejajar atau seri, tergantung dari peruntukannya, guna menghasilkan daya dengan kombinasi tegangan danarus yang dikehendaki.

Cahaya matahari terdiri atas foton atau partikel energi surya, dimana foton inilah yang dikonversi menjadi energi listrik. Foton-foton mengandung energi yang bervariasi menurut panjang gelombangnya. Energi foton yang diserap oleh sel surya diserahkan sebagian atau seluruhnya kepada elektron di dalam sel surya. Dengan adanya energi baru ini maka elektron mampu lepas dari posisi normalnya terhadap atom sehingga menjadi arus dalam suatu sirkuit listrik. 


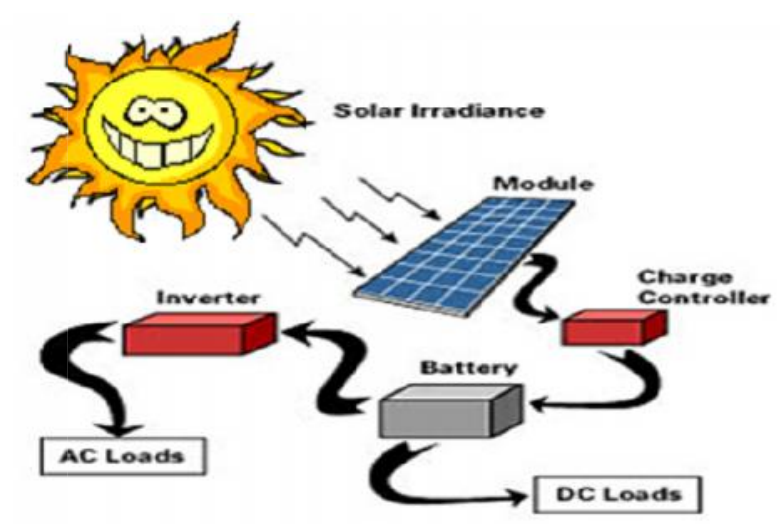

Gambar 1. Proses terjadinya energi listrik dari tenaga surya

Listrik tenaga matahari dibangkitkan oleh komponen yang disebut solar cell yang besarnya sekitar 10 15 cm persegi.Komponen inimengkonversikan energi dari cahaya matahari menjadi energi listrik. Solar cell merupakan komponen vital yang umumnya terbuat dari bahan semikonduktor.

Rata-rata Produk Modul yang dipasarkan menghasilkan 12 sampai 18 VDC dengan arus 0,5 sampai 7 Ampere. Modul memiliki kapasitas beraneka ragam, mulai dari 10 watt peak sampai 200 watt peak.

\section{Kelebihan Pembangkit Listrik Tenaga Surya}

* Energi yang terbarukan/ tidak pernah habis

* Bersih, ramah lingkungan

* Umur panel sel surya panjang/ investasi jangka panjang

* Praktis, tidak memerlukan perawatan

* Sangat cocok untuk daerah tropis seperti Indonesia

Umumnya kita menghitung maksimun sinar matahari yang diubah menjadi tenaga listrik sepanjang hari efektifnya adalah 5 jam. Tenaga listrik pada pagi - sore disimpan dalam baterai, dan akan digunakan pada malam hari.

\section{Komponen Pembangkit Listrik Tenaga Surya}

Untuk instalasi listrik tenaga surya sebagai pembangkit listrik, diperlukan komponen sebagai berikut:

\section{Panel Surya (Solar Cell)}

Sel silikon (disebut juga solar cells) yang disinari matahari menimbulkan tegangan yang kemudian memaksa photon melepaskan elektron yang DESAIN PEMBANGKIT LISTRIK TENAGA SURYA PADA DAERAH PESISIR KUALA TUNGKAL TANJAB BARAT 
menghasilkan arus listrik. Sebuah solar cells menghasilkan kurang lebih tegangan 0.5 Volt. Jadi sebuah panel surya 12 Volt terdiri dari kurang lebih 36 sel (untuk menghasilkan 17 Volt tegangan maksimun).

\section{Charge Control}

Pada waktu solar panel mendapatkan energy dari cahaya matahari di siang hari, rangkaian charger controller ini otomatis bekerja dan mengisi (charge) battery dan menjaga tegangan battery agar tetap stabil .

Bila kita menggunakan battery $12 \mathrm{~V}$, maka rangkaian ini akan menjaga agar tegangan charger $12+10 \%$, tegangan charger yang di butuhkan antara 13,2 - 13,4 Volt. Dan bila sudah mencapai tegangan tersebut, rangkaian ini otomatis akan menghentikan proses pengisian battery.

\section{Battery}

Battery berfungsi sebagai tempat untuk menyimpan daya (power storage).

Battery yang digunakan sebaiknya menggunakan battery gel atau yang selama ini kita kenal dengan istilah battery kering.Battery gel ini adalah yang paling direkomendasikan untuk digunakan pada applikasi solar system.

\section{Inverter (Optional)}

Inverter adalah perangkat elektrik yang mengkonversikan tegangan searah (DC direct current) menjadi tegangan bolak balik (AC - alternating current).

\section{Perencanaan Pembangkit Listrik Tenaga Surya}

Karena pembangkit listrik tenaga surya sangat tergantung kepada sinar matahari, maka perencanaan yang baik sangat diperlukan. Perencanaan terdiri dari:

- Jumlah daya yang dibutuhkan dalam pemakaian sehari-hari (Watt).

- Berapa besar arus yang dihasilkan solar cells panel (dalam Ampere hour), dalam hal ini memperhitungkan berapa jumlah panel surya yang harus dipasang.

- Berapa unit baterai yang diperlukan untuk kapasitas yang diinginkan dan pertimbangan penggunaan tanpa sinar matahari. (Ampere hour).

Dari sisi waktu nilai ke-ekonomian PLTS juga tinggi, karena dengan perencanaan yang baik, pembangkit listrik tenaga surya dengan panel surya memiliki daya 
tahan 20 - 25 tahun. Baterai dan beberapa komponen lainnya dengan daya tahan 3 -5 tahun.

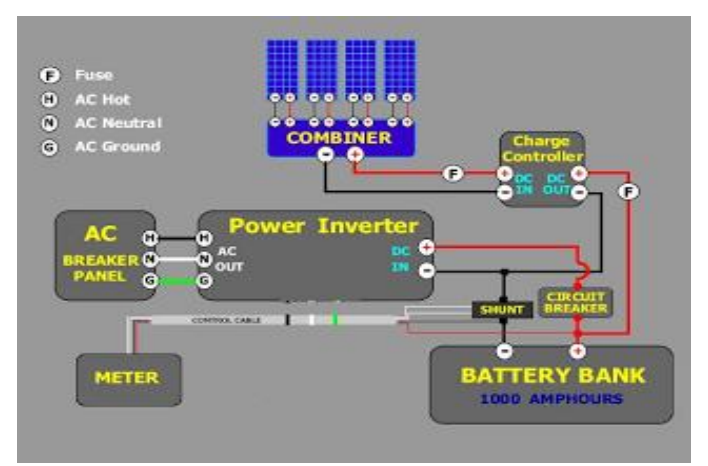

Gambar 2. Diagram pembangkit solar panel

Dari diagram pembangkit listrik tenaga surya diatas: beberapa solar panel di paralel untuk menghasilkan arus yang lebih besar. Combiner pada gambar diatas menghubungkan kaki positif panel surya satu dengan panel surya lainnya. Kaki/ kutub negatif panel satu dan lainnya juga dihubungkan. Ujung kaki positif panel surya dihubungkan ke kaki positif charge controller, dan kaki negatif panel surya dihubungkan ke kaki negatif charge controller. Tegangan panel surya yang dihasilkan akan digunakan oleh charge controller untuk mengisi baterai. Untuk menghidupkan beban perangkat AC (alternating current) seperti Televisi, Radio, komputer, dll, arus baterai disupply oleh inverter.

Keuntungan dari pembangkit listrik tenaga matahri :

1. Sumber energi yang dipakai tidak pernah habis dan sangat ramah lingkungan

2. Tidak memerlukan perawatan kusus sehingga bebas dari segala biaya perawatan

3. Hemat karena tidak memerlukan bahan bakar

4. Bersifat moduler artinya kapasitas listrik yang dihasilkan dapat sesuai dengan kebutuhan

5. Tanpa suara sehingga tidak mengganggu ketertiban umum

6. Ramah lingkungan 


\section{Metode Penelitian}

Pada penelitian ini dilakukan pengukuran pada titik yang telah ditetapkan untuk diketahui jumlah cahaya yang terpapar pada luasan unit solar panel di wilayah kota Kuala Tungkal dengan menggunakan alat lux meter. Data yang didapat dari alat lux meter dicatat dan juga dicatat besar tegangan dan arus yang dihasilkan oleh perangkat solar panel $200 \mathrm{wp}$ yang diletakan pada tempat tersebut. Data diambil setiap satu jamsetiap hari dan dilakukan selama 6 hari.Data yang didapat tersebut akan langsung terkonversi menjadi energi listrik dalam bentuk arus searah (DC).

\section{DATA}

Tabel 1. Data pada hari Senin tgl 1 Agustus 2016

\begin{tabular}{|c|c|c|c|c|}
\hline No & Waktu & $\begin{array}{c}\text { Intensitas Cahaya } \\
\text { Matahari (Lux) }\end{array}$ & $\begin{array}{c}\text { Tegangan } \\
\text { Out (V) }\end{array}$ & $\begin{array}{c}\text { Arus Out } \\
(\mathrm{I})\end{array}$ \\
\hline 1 & $7.00-8.00$ & 5.295 & 18,5 & 0,27 \\
\hline 2 & $8.00-9.00$ & 6.411 & 18,9 & 0,32 \\
\hline 3 & $9.00-10.00$ & 7.844 & 18,5 & 0,4 \\
\hline 4 & $10.00-11.00$ & 9.805 & 18,5 & 0,5 \\
\hline 5 & $11.00-12.00$ & 11.382 & 18,2 & 0,59 \\
\hline 6 & $12.00-13.00$ & 14.254 & 18,94 & 0,71 \\
\hline 7 & $13.00-14.00$ & 10.371 & 18,46 & 0,53 \\
\hline 8 & $14.00-15.00$ & 7.928 & 16,62 & 0,45 \\
\hline 9 & $15.00-16.00$ & 5.877 & 16,8 & 0,33 \\
\hline 10 & $16.00-17.00$ & 3.005 & 13,5 & 0,21 \\
\hline \multicolumn{4}{|c|}{ Jumlah arus yang terkumpul } \\
\hline
\end{tabular}

Ket mulai jam 15.00 hingga jam 17.00 langit lebih gelap

Tabel 2. Data pada hari Selasa tgl 2 Agustus 2016

\begin{tabular}{|c|c|c|c|c|}
\hline No & Waktu & $\begin{array}{c}\text { Intensitas Cahaya } \\
\text { Matahari (Lux) }\end{array}$ & $\begin{array}{c}\text { Tegangan } \\
\text { Out (V) }\end{array}$ & $\begin{array}{c}\text { Arus Out } \\
(\mathrm{I})\end{array}$ \\
\hline 1 & $7.00-8.00$ & 8.722 & 18,7 & 0,44 \\
\hline 2 & $8.00-9.00$ & 7.899 & 18,63 & 0,4 \\
\hline 3 & $9.00-10.00$ & 8.544 & 18,32 & 0,44 \\
\hline 4 & $10.00-11.00$ & 11.106 & 18,71 & 0,56 \\
\hline 5 & $11.00-12.00$ & 11.588 & 18,22 & 0,6 \\
\hline
\end{tabular}

DESAIN PEMBANGKIT LISTRIK TENAGA SURYA PADA DAERAH PESISIR KUALA TUNGKAL TANJAB BARAT 


\begin{tabular}{|c|c|c|c|c|}
\hline 6 & $12.00-13.00$ & 11.550 & 18,16 & 0,6 \\
\hline 7 & $13.00-14.00$ & 8.259 & 18,12 & 0,43 \\
\hline 8 & $14.00-15.00$ & 7.287 & 18,09 & 0,38 \\
\hline 9 & $15.00-16.00$ & 2.079 & 17,83 & 0,11 \\
\hline 10 & $16.00-17.00$ & 7.539 & 16,54 & 0,43 \\
\hline \multicolumn{2}{|r|}{ Jumlah arus yang terkumpul } & 4,39 \\
\hline
\end{tabular}

Ket mulai 15.00 hingga 16.00 langit berawan gelap berhujan sedikit

Tabel 3. Data pada hari Rabu tgl 3 Agustus 2016

\begin{tabular}{|c|c|c|c|c|}
\hline No & Waktu & $\begin{array}{c}\text { Intensitas Cahaya } \\
\text { Matahari (Lux) }\end{array}$ & $\begin{array}{c}\text { Tegangan } \\
\text { Out (V) }\end{array}$ & $\begin{array}{c}\text { Arus Out } \\
(\mathrm{I})\end{array}$ \\
\hline 1 & $7.00-8.00$ & 7.899 & 18,63 & 0,4 \\
\hline 2 & $8.00-9.00$ & 8.569 & 18,8 & 0,43 \\
\hline 3 & $9.00-10.00$ & 8.722 & 18,7 & 0,44 \\
\hline 4 & $10.00-11.00$ & 9.821 & 18,53 & 0,5 \\
\hline 5 & $11.00-12.00$ & 10.165 & 13,7 & 0,7 \\
\hline 6 & $12.00-13.00$ & 10.039 & 13,53 & 0,7 \\
\hline 7 & $13.00-14.00$ & 9.172 & 18,81 & 0,46 \\
\hline 8 & $14.00-15.00$ & 7.177 & 18,3 & 0,37 \\
\hline 9 & $15.00-16.00$ & 5.021 & 18,22 & 0,26 \\
\hline 10 & $16.00-17.00$ & 2.916 & 18,34 & 0,15 \\
\hline \multicolumn{4}{|c|}{ Jumlah arus yang terkumpul } & 4,41 \\
\hline
\end{tabular}

16.00-17.00 langit kembali gelap dan ada hujan

Tabel 4. Data pada hari Kamis tgl 4 Agustus 2016

\begin{tabular}{|c|c|c|c|c|}
\hline No & Waktu & $\begin{array}{c}\text { Intensitas Cahaya } \\
\text { Matahari (Lux) }\end{array}$ & $\begin{array}{c}\text { Tegangan } \\
\text { Out (V) }\end{array}$ & $\begin{array}{c}\text { Arus Out } \\
(\mathrm{I})\end{array}$ \\
\hline 1 & $7.00-8.00$ & 4.325 & 16,32 & 0,25 \\
\hline 2 & $8.00-9.00$ & 5.877 & 16,8 & 0,33 \\
\hline 3 & $9.00-10.00$ & 7.899 & 18,63 & 0,4 \\
\hline 4 & $10.00-11.00$ & 11.838 & 17,45 & 0,64 \\
\hline 5 & $11.00-12.00$ & 11.618 & 13,7 & 0,8 \\
\hline 6 & $12.00-13.00$ & 10.039 & 13,53 & 0,7 \\
\hline 7 & $13.00-14.00$ & 7.109 & 18,63 & 0,36 \\
\hline 8 & $14.00-15.00$ & 7.371 & 18,3 & 0,38 \\
\hline 9 & $15.00-16.00$ & 3.806 & 16,32 & 0,22 \\
\hline 10 & $16.00-17.00$ & 3.952 & 18,64 & 0,2 \\
\hline \multicolumn{4}{|c|}{ Jumlah arus yang terkumpul } \\
\hline
\end{tabular}

DESAIN PEMBANGKIT LISTRIK TENAGA SURYA PADA DAERAH PESISIR KUALA TUNGKAL TANJAB BARAT 
Cuaca normal hingga sore hari

Tabel 5. Data pada hari Jumat tgl 5 Agustus 2016

\begin{tabular}{|c|c|c|c|c|}
\hline No & Waktu & $\begin{array}{c}\text { Intensitas Cahaya } \\
\text { Matahari (Lux) }\end{array}$ & $\begin{array}{c}\text { Tegangan } \\
\text { Out (V) }\end{array}$ & $\begin{array}{c}\text { Arus Out } \\
(\mathrm{I})\end{array}$ \\
\hline 1 & $7.00-8.00$ & 8.131 & 18,71 & 0,41 \\
\hline 2 & $8.00-9.00$ & 8.968 & 18,8 & 0,45 \\
\hline 3 & $9.00-10.00$ & 8.996 & 18,86 & 0,45 \\
\hline 4 & $10.00-11.00$ & 10.017 & 18,53 & 0,51 \\
\hline 5 & $11.00-12.00$ & 5.162 & 18,73 & 0,26 \\
\hline 6 & $12.00-13.00$ & 4.638 & 18,23 & 0,24 \\
\hline 7 & $13.00-14.00$ & 3.633 & 18,04 & 0,19 \\
\hline 8 & $14.00-15.00$ & 7.287 & 18,09 & 0,38 \\
\hline 9 & $15.00-16.00$ & 5.021 & 18,22 & 0,26 \\
\hline 10 & $16.00-17.00$ & 3.276 & 18,18 & 0,17 \\
\hline \multicolumn{4}{|c|}{ Jumlah Arus yang terkumpul } & 3,32 \\
\hline
\end{tabular}

Cuaca berawan mulai 9.00 hingga sore hari tapi tidak hujan

Tabel 6. Data pada hari Sabtu tgl 6 Agustus 2016

\begin{tabular}{|c|c|c|c|c|}
\hline No & Waktu & $\begin{array}{c}\text { Intensitas Cahaya } \\
\text { Matahari (Lux) }\end{array}$ & $\begin{array}{c}\text { Tegangan } \\
\text { Out (V) }\end{array}$ & $\begin{array}{c}\text { Arus Out } \\
(\mathrm{I})\end{array}$ \\
\hline 1 & $7.00-8.00$ & 8.131 & 18,71 & 0,41 \\
\hline 2 & $8.00-9.00$ & 8.968 & 18,8 & 0,45 \\
\hline 3 & $9.00-10.00$ & 8.996 & 18,86 & 0,45 \\
\hline 4 & $10.00-11.00$ & 10.017 & 18,53 & 0,51 \\
\hline 5 & $11.00-12.00$ & 5.162 & 18,73 & 0,26 \\
\hline 6 & $12.00-13.00$ & 4.638 & 18,23 & 0,24 \\
\hline 7 & $13.00-14.00$ & 3.633 & 18,04 & 0,19 \\
\hline 8 & $14.00-15.00$ & 7.287 & 18,09 & 0,38 \\
\hline 9 & $15.00-16.00$ & 5.021 & 18,22 & 0,26 \\
\hline 10 & $16.00-17.00$ & 3.276 & 18,18 & 0,17 \\
\hline \multicolumn{4}{|c|}{ Jumlah arus yang terkumpul } & 3,32 \\
\hline
\end{tabular}

Cuaca berawan mulai 10.00 hingga sore hari tapi tidak hujan

Dalam 6 hari pengambilan data tersebut dapat dikumpulkan arus listrik yang masuk kedalam baterai sebagai berikut :

DESAIN PEMBANGKIT LISTRIK TENAGA SURYA PADA DAERAH PESISIR KUALA TUNGKAL TANJAB BARAT 
$\begin{array}{llll}\text { Hari } 1 & =4,43 \mathrm{~A} & \text { Hari } 2=4,39 \mathrm{~A} & \text { Hari } 3=4,41 \mathrm{~A} \\ \text { Hari } 4 & =4,28 \mathrm{~A} & \text { Hari } 5=3,32 \mathrm{~A} & \text { Hari } 6=3,32 \mathrm{~A}\end{array}$

Arus yang terkumpul masing-masing dalam satu hari tersebut sesuai dengan kondisi cuaca pada hari tersebut. Pada hari ke5 dan ke 6 sebelum siang hari telah terjadi awan yang menghalangi masuknya sinar matahari kepada alat solar panel yanh bertugas untuk mengkonversikan sinar matahari.

Dengan mengasumsikan effisiensi inverter $100 \%$, maka dengan alat solar panel 200 wp pada hari pertama dapat dimanfaatkan sejumlah 948 Wh yang dapat dimanfaatkan, sedangkan pada hari kedua adalah sebanyak $965 \mathrm{Wh}$ yang dapat dimanfaatkan. Untuk hari ketiga sebanyak 970 Wh yang dapat dikumpulkan dan pada hari ke empat $941 \mathrm{Wh}$, untuk hari ke lima dan ke enam adalah sebanyak 730 Wh.

\section{Disain Solar Panel}

Untuk menentukan seberapa banyak unit panel surya dan baterai yang dibutuhkan untuk keperluan satu malam pada satu keluarga ditentukan oleh seberapa banyak beban listrik yang akan dioperasionalkan.

Dicontohkan pada satu keluarga terdiri dari ayah, ibu, kakek, nenek dan dua orang anak. Dengan jumlah anggota keluarga tersebut maka dibutuhkan minimal 3 kamar tidur dan 2 wc. Jumlah ruangan yang terdapat pada rumah sederhana tersebut adalah 8 dengan titik lampu sebanyak 12 buah. Untuk lampu penerangan setiap ruangan dibutuhkan $15 \mathrm{w}$ dengan jumlah jam hidup 6 jam, kecuali lampu teras yaitu 12 jam. Kulkas sedang dengan daya $100 \mathrm{w}$ yang hidupnya 24 jam. Namun untuk kulkas kompresornya tidak selalu hidup, maka waktu kerjanya adalah $1 / 3 * 24$ jam $=8$ jam. Pompa air $125 \mathrm{w}$ yang hidupnya maksimal $2 \mathrm{kali}$ dalam 1 hari 1malam. Kemudian 2 buah televisi Lcd 32 inch berdaya 100 w yang hidup selama 6 jam. 3 buah pendingin udara 1/2 PK untuk masing-masing kamar yang bekerja selama 7 jam. Dengan tabel berikut dapat dijumlahkan kebutuhan daya listrik rumah sederhana tersebut dalam satu hari:

Tabel 7. Jumlah kebutuhan daya listrik 


\begin{tabular}{|c|l|c|c|c|r|}
\hline No & \multicolumn{1}{|c|}{ Alat } & Jumlah & Daya & Waktu hidup & \multicolumn{1}{c|}{ Jumlah } \\
\hline 1 & Lampu penerangan & 12 & $15 \mathrm{~W}$ & 6 jam & 1.080 \\
\hline 2 & Lampu Teras & 1 & $15 \mathrm{~W}$ & 12 jam & 180 \\
\hline 3 & Kulkas & 1 & $100 \mathrm{~W}$ & 8 jam & 800 \\
\hline 4 & Pompa air & 1 & $125 \mathrm{~W}$ & 2 jam & 250 \\
\hline 5 & Televisi Lcd 32 & 2 & $100 \mathrm{~W}$ & 6 jam & 1.200 \\
\hline 6 & Pendingin Udara $1 / 2 \mathrm{pk}$ & 3 & $411 \mathrm{~W}$ & 7 jam & 8.631 \\
\hline 7 & Lain-lain & 1 & $200 \mathrm{~W}$ & 3 jam & 600 \\
\hline & \multicolumn{3}{|c}{ Total } & 12.741 \\
\hline
\end{tabular}

Dengan kondisi rumah sederhana seperti diatas, maka kebutuhan daya listrik untuk rumah tersebut adalah 12,741 Watt. Dan jika dikalikan dengan faktor konversi dan effisiensi peralatan, maka kebutuhan menjadi 15,289 watt dalam satu hari.

Untuk menentukan jumlah baterai yang dibutuhkan dapat dihitung sebagai berikut : $15,289 \mathrm{~W} / 12 \mathrm{~V}=1,274 \mathrm{~A}$

Dan jika baterai yang digunakan adalah 100Ah, maka kebutuhan baterainya adalah : 1274 / $100=12,74$ dibulatkan menjadi 13 buah baterai dengan kapasitas $100 \mathrm{Ah}$

Dengan menggunakan solar panel 200 wp artinya dalam 1 jam akan dapat dihasilkan listrik sebanyak 200 watt dalam cuaca yang terik. Jika diasumsikan panas terik itu terjadi mulai jam 10 hingga jam 15, maka akan didapat 1000 watt dalam 1 hari untuk satu modul solar panel. Maka kebutuhan modul solar panel tipe 200 wp untuk memenuhi kebutuhan diatas adalah $15289 / 1000=15,3$ dibulatkan menjadi 16 unit.

Namun jika tidak menggunakan pendingin udara maka kebutuhan batrai dan unit akan berkurang yaitu :

$$
12741-8631=4110 \mathrm{~W} \text {. }
$$

Dengan menambahkan faktor konversi dan effisiensi, maka daya listrik yang dibutuhkan adalah $=4932 \mathrm{~W}$

$$
\text { Maka } 4932 \mathrm{~W} / 12 \mathrm{~V}=411 \mathrm{~A}
$$

Dengan menggunakan batterai 100 Ah, maka dibutuhkan 5 buah baterai (dibulatkan)

\section{DESAIN PEMBANGKIT LISTRIK TENAGA SURYA PADA DAERAH PESISIR KUALA} TUNGKAL TANJAB BARAT 
Untuk kebutuhan suplai maka :

$$
4932 / 1000=4,6 \text { dibulatkan menjadi } 5 \text { unit }
$$

\section{Kesimpulan}

Dari penelitian diatas dapatlah disimpulkan bahwa sumber energi dari matahari bisa dimanfaatkan untuk memenuhi kebutuhan energi listrik masyarakat.

Hambatan yang masih sering terjadi pada penggunaan PLTS ini adalah pada tidak dapatnya diprediksi keacaan cuaca dalam waktu sesaat, sehingga produksi energi listrik dapat memenuhi target yang diharapkan, dan hal ini membuat ketidak nyamanan pengguna.

Selain itu harga unit solar panel ini untuk saat ini masih tergolong mahal, baik untuk pembelian awal, maupun untuk perawatan.

\section{Saran}

Perlunya penelitian terhadap efisiensi modul solar panel, karena saat ini efisiensi yang dihasilkan modul solar panel masih sangat rendah, sehingga untuk mendapatkan $1 \mathrm{KWh}$ energi listrik masih tergolong sangat mahal. 


\section{DAFTAR PUSTAKA}

Arismunandar. A, Kuwahara. S, 2004, Teknik Tenaga Listrik, Gardu Induk, Pradnya Paramita Jakarta

Arvin Grabel at al. 2003. "Problem in magnetic induction for full voltage production". IEEE Trans. on Industry Applications, Vol.7 No. 2 June 2003. p $433-438$.

Marsudi, Djiteng., 2006, Operasi Sistem Tenaga Listrik, Graha Ilmu Yogyakarta

Butar-butar, Abdul Hakim, 2000, Manajemen Faktor Daya di Industri, Energi, Yogyakarta

Charles W at al. 2003. " Current and voltage force in small electric generator ". IEEE Trans On PWRD Vol.4. No. 2. p. 329. 2003.

Dally, James W. 1999. "Instrumentation for Engineering Measurements". John Wiley \& Sons, Inc, p.605.

www.esdm.go.id/publikasi/.../714-blue-print-pengelolaan-energi-nasiona

DeGarmo Paul E Sulllivan GW Bontadelli A J \& Wicks M Elin, 1997 Engineering Economy, Tenth Edition, Prentice Hall

Endro, Herman, 2003, Teknik Penghematan Energi Pada System Pencahayaan, Bagian Proyek Pelaksanaan Efisiensi Energi DEPDIKNAS. Jakarta

Hayt Kemmerly at al. 2002. "RLC caracteristic serie in over load electric generator". IEEE Trans. On Industry Appl. Vol.6. No. 1. Jan. 2002. p 213 -217 .

Peter G at al. 2000. " Design small electric generation and Low Excitation " IEEE Trans. On PWRD. Jun/Jul. 2000. Vol.3. No.2. p. 132

Warsito,2003, Sosialisasi dan Evaluasi diri Konservasi Energi Universitas Diponegoro tahun 2003, Badan Penerbit Universitas Diponegoro, 